\title{
A STANDARD METHOD FOR DEMONSTRATION OF THE LIFE CYCLE OF DERMATOPHILUS CONGOLENSIS
}

\author{
B. SKALKA ${ }^{1}$ and L. POSPIŠIL ${ }^{2}$ \\ ${ }^{1}$ Department of Microbiology and Immunology, University of Veterinary and Pharmaceutical Sciences, \\ 61242 Brno \\ 2 Department of Microbiology, Faculty of Medicine, Masaryk University, St. Ann's Hospital, 65691 Brno, \\ Czech Republic
}

Received May 7, 1993

\begin{abstract}
Skalka B. and L. Pospíšil: A standard method for demonstration of the life cycle of Dermatophilus congolensis. Acta vet. Brno, 62, 1994: 3-7.

Determination of the life cycle of Dermatophilus congolensis is a prerequisite for its diagnosis. Attempts to demonstrate the life cycle of $D$. congolensis in preparations are successful only now and then even when nutrient-rich media for its cultivation are used. Enrichment of the media with sterile rabbit blood serum stimulates typical septation of the hyphae and intratubular development of the spores, which is the unique characteristic of this species. Preparations from the media enriched with blood serum regularly contain all stages of the life cycle of $D$. congolensis and thus make its accurate diagnosis possible.
\end{abstract}

Dermatophilus congolensis, life cycle, enrichment of media with sterile serum.

Dermatophilus congolensis Van Saceghem 1915, 357, emend. mut. char. Gordon 1964, the causative agent of dermatophilosis of animals and man, is characterized by its unique life cycle, at the beginning and at the end of which are motile zoospores of $0.5 \mu \mathrm{m}$ in diameter. Upon germination they lose flagella and develop into tubular forms, generally up to $5 \mu \mathrm{m}$ wide and extremely long, branching laterally at right angles and slightly conical in form. The substrate mycelium developing on solid medium gives rise to a colony. This process also takes place in liquid medium, being manifested by a membrane and by the development of flocculi or small granules. The internal transverse and longitudinal branching of tubular hyphae creates septa in which new spores develop. After being released from the septa the zoospores are motile for a certain period of time and their germination marks the beginning of a new life cycle (Roberts 1961; Gord on and Edwards 1963; Gordon 1964; Gy les 1986; Gordon 1989). D. congolensis is intensively Gram-positive.

Attemps to detect the life cycle of $D$. congolensis in fixed stained preparations often fail to yield positive results because of different multiplication rates of the strains and because of the culture medium employed (Pospís il et al. 1992). To determine the conditions permitting regular demonstration of the life cycle of this species in fixed stained preparations was the objective of the present study.

\section{Bacterial strains}

\section{Materials and Methods}

Five strains of $D$. congolensis were used. Of these one strain was isolated by us (Pospísil et al. 1991), two strains were from the National Collection of Type Cultures (NCTC), London, namely strains 5175 and 7915, and the remaining two from the Norwegian College of Veterinary Medicine, Oslo, namely strains N-A and N-L. All five strains are deposited in the Czechoslovak National Collection of Type Cultures (CNCTC), Prague, under code designation of Dc 1/91, Dc 2/91, Dc 3/91, Dc 4/91 and Dc 5/91, respectively.

\section{Culture media}

Tryptone Soya Agar (TSA) CM 131, Tryptone Soya Broth (TSB) CM 129, Columbia Blood Agar Base (CBA) CM 331, Brain Heart Infusion (BHI) CM 225 and Brain Heart Infusion Agar CM 375, all of them Oxoid Ltd, were used. The media were used both unsupplemented and supplemented with $25 \%(\mathrm{v} / \mathrm{v})$ sterile rabbit serum. The agar media were also supplemented with 5\% (v/v) sheep erythrocytes after three washings.

Prerarations for microscopic examination

All five $D$. congolensis strains growing in the afore-mentioned media were examined by microscope in fixed preparations stained according to Gram. The materials were collected after $14 \mathrm{~h}, 18 \mathrm{~h}, 24 \mathrm{~h}, 36 \mathrm{~h}$ and $48 \mathrm{~h}$ 
of aerobic incubation at $37^{\circ} \mathrm{C}$. The materials from the solid media were collected directly from the colonies and those from the liquid media, after their centrifugation and subsequent re-suspension of the sediment in saline.

\section{Results}

The five $D$. congolensis strains grew equally well on all media employed. On the solid media their colonies grew into the surface in the form of pits. On the blood agar media they produced zones of complete haemolysis. In the liquid media not supplemented with serum they grew as a sediment of minute flocculi in clear medium. In serum-supplemented broth media they grew in the form of a membrane that was either located at the bottom of the test tube or was floating in the clear medium, being reminiscent of a very delicate lace.

Preparations from the solid media without serum, both from those unsupplemented and from blood agar media, contained only Gram-positive spores and merely rudimentary filaments if the material was withdrawn carefully from the surface of the medium (Fig. 1). Where the materials were collected from the disrupted surface together with parts of the colonies or with the flocculi from the liquid medium sediment, they contained branching mycelial forms showing no marked tendency to the intratubular formation of septa and spores, this phenomenon being observed only exceptionally. The above-described microscopic picture was seen in preparations made within $24 \mathrm{~h}$ of incubation, whereas those made after a longer period of time contained only spores.

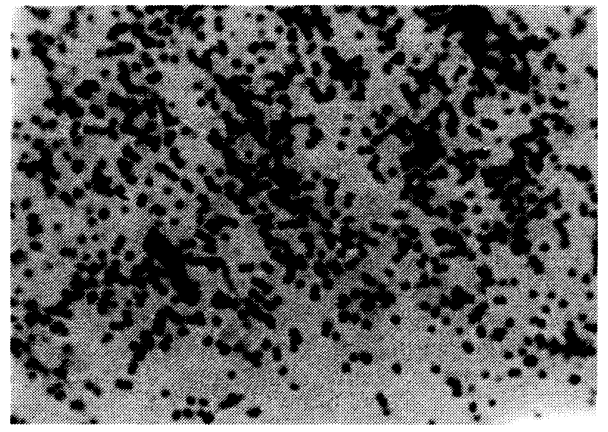

Fig. 1. Loospores of D. congolensis. $\times 1800$.

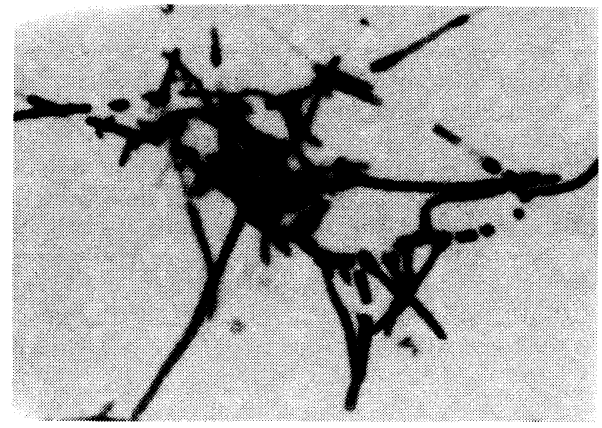

Fig. 2. Filamentous forms of $D$. congolensis showing incipient septation and intratubular development of spores. $\times 1800$.

The regular incidence of typically septed filaments was recorded for all five $D$. congolensis strains in preparations from both solid and liquid media enriched with blood serum. After as few as $14 \mathrm{~h}$ of incubation, filaments showing incipient septation and development of spores were observed (Fig. 2). After 18 and $24 \mathrm{~h}$ incubation, septation of the hyphae and intratubular development of the spores became increasingly distinct and this phase of the life cycle outnumbered the other stages detectable in the preparations (Fig. 3). Released zoospores, often arranged as they were observed in the septed hyphae, were seen in preparations from these media after $36 \mathrm{~h}$ and $48 \mathrm{~h}$ incubation (Fig. 4), although the remaining phases of the life cycle of $D$. congolensis were also present. 


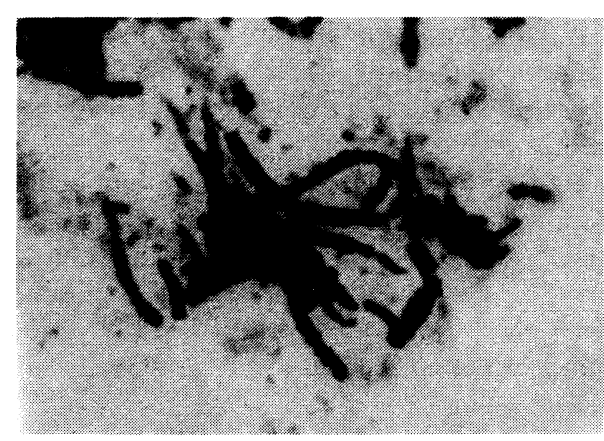

Fig. 3. Septed hyphae of $D$. congolensis showing developed intratubular spores. x 1800 .

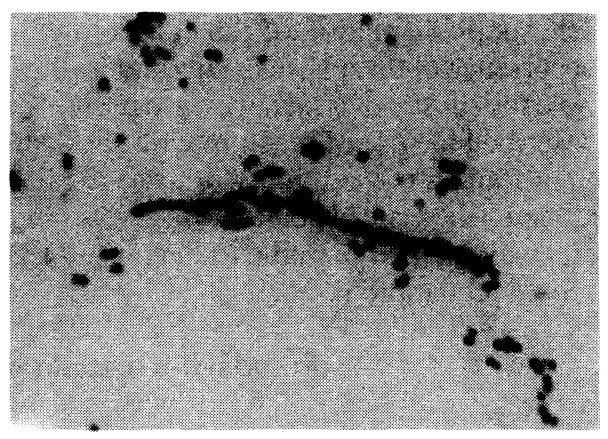

Fig. 4. D. congolensis zoospores recently released after disappearance of the hyphae. x 1800. (Note: The strain shown in Figs. 1 to 4 is D. congolensis strain Dc 1/91.)

\section{Discussion}

Dermatophilosis of animals and man is still regarded as a skin disease posing diagnostic problems; for its accurate diagnosis, detection of the causative agent is a necessity (Pos pi šil et al. 1991, 1992; V e s t w e ber 1992). Recent isolations in Europe from both farm animals (B a u stad et al. 1989; Hannes et al. 1991) and man (Hänel et al. 1991; Pos pí šil et al. 1991) have drawn attention to the fact that this species can also be found under European conditions. Microbiologists should therefore be aware about all the $D$. congolensis characteristics that make its accurate diagnosis possible.

Although $D$. congolensis grows even on common nutrient agar, recommendations have been made for its isolation and passage on nutrient-rich media (G yle s 1986; Gord on 1989). In a previous study we found that $D$. congolensis strains grew better on Columbia agar (CBA) than on BHI agar (Pos píšil et al. 1992). This was confirmed in the present study where this moderate difference, however, was reduced by the supplementation with blood serum. A marked difference was observed only in the form of growth in the liquid media with blood serum.

With the aim to make macroscopic diagnosis of $D$. congolensis on culture media more accurate our previous reports have described haemolysin interactions of this species with exosubstances of other bacterial species, particularly with CAMP factor of Streptococcus agalactiae, equi factor of Rhodococcus equi and staphylococcal beta and delta haemolysins ( $\mathrm{Skalka}$ and Pospíšl 1992) as well as the possibility of serum diagnosis on the basis of the demonstration of antigenic identity of haemolysin produced by various $D$. congolensis strains ( Skalka and Pospíšil 1993a).

Nevertheless, attempts to detect all phases of the life cycle of $D$. congolensis in fixed stained preparations from strain cultures may not necessarily succeed; this applies particularly to the septation of hyphae and to the intratubular development of zoospores. The dependence of the detection upon culture conditions has been described (Gord on 1989). This phase, however, was regularly detected in histological preparations from pathological lesions in both natural and experimental infection (Pospíšil et al. 1991; B uček et al. 1992). In the relevant literature the occurrence of septed hyphae was reported mainly in histological preparations (Roberts 1965; Gyles 1986; Vestweber 1992) and only rarely in materials from culture media (Gord on 1964).

Our previous problems with demonstration of this $D$. congolensis life cycle phase which is of paramount diagnostic value (Gordon 1989) gave an impetus to the present study. 
The supplementation of the culture media with blood serum was inspired by the regular occurrence of this phase in vivo and by the fact that none of the published studies on this species, the survey of which we have presented elsewhere ( $\mathrm{Skalka}$ and Pospísil 1993b), described the use of medium with sterile blood serum.

In stained preparations from the media containing $25 \%$ sterile rabbit serum the occurrence of the typical septed forms was a regular finding. Therefore media supplemented in this way make it possible to diagnose $D$. congolensis accurately on the basis of the microscopic preparation.

\section{Standardní metoda pro průkaz životního cyklu Dermatophilus congolensis}

Určení životního cyklu Dermatophilus congolensis je základním požadavkem pro diagnostiku tohoto druhu. Úplný průkaz životního cyklu se daří jen nepravidelně v preparátech i při použití nutričně bohatých médií pro kultivaci $D$. congolensis. Obohacení médií nativním krevním sérem stimuluje typickou septaci hyf a intratubulární vznik spór, což je jedinečnou vlastností tohoto druhu. Preparáty z médií obohacených krevním sérem obsahují pravidelně všechna stadia životního cyklu a tak umožňují přesnou diagnostiku $D$. congolensis.

\section{Стандартный мөтод опредөлөния жизнөнного цикла Dermatophilus congolensis}

Определение жизненного цикла Dermatophilus congolensis является основным требованием диагностики данного характера. Полное доказательство удается в определении жизненного цикла не всегда в препаратох даже при использовании питательно обильных средств для культивирования D. congolensis. Обогащение средств нативной кровяной сывороткой стимулирует характерную септацию гифов и интратубулярное возникновение спор, что является уникальным свойством данного вида. Препараты, обогащенные кровяной сывороткой, содержат, как правило, все стадии цикла жизни, способствуя, таким образом, точной диагностике D. congolensis.

\section{References}

BAUSTAD, B.-SVEBERG, G.-NILSEN, H.-PEDERSEN, H.-RYENG, K.-SØRENSEN, K.: Dermatofilose en ,ny“" hudsykdom pa hest. Norsk Veterinaertidsskrift, 101, 1989: 245-250.

BUČEK, J.-POSPISILIL, L.-MOSTER, M.-SKALKA, B.: Experimental dermatophilosis. J. Vet. Med. B 39, 1992: 459-502.

GORDON, M. A.: The genus Dermatophilus. J. Bacteriol., 88, 1964: 509-522.

GORDON, M. A.: Genus Dermatophilus Van Saceghem 1915, emend. mut. char. Gordon 1964, p. 2409-2410. In: WILLIAMS, S. T.-SHARPE, M. E.-HOLT, J. G. (eds.): Bergey's Manual of Systematic Bacteriology, Vol. 4. Williams and Wilkins. Baltimore, Hong Kong, London, Sydney 1989.

GORDON, M. A.-EDWARDS, M.: Micromorphology of Dermatophilus congolensis. J. Bacteriol., 86, 1963: $1101-1115$.

GYLES, C. L.: Nocardia; Actinomyces; Dermatophilus. p. 87-94. In: GYLES, C. L.-THOEN, C. O. (eds.): Pathogenesis of Bacterial Infections in Animals. Iowa State University Press. Ames 1986.

HÂNEL, H.-KALISCH, J.-KEIL, M.-MARSCH, W. C.-BUSLAU, M.: Quantification of keratinolytic activity from Dermatophilus congolensis. Med. Microbiol. Immunol., 180, 1991: 45-51.

HANNES, C.-DOM, P.-HAESEBROUCK, F.-DEVRIESE, L.: The first isolation in Belgium of Dermatophilus congolensis from a cow. Vlaams Diergeneeskundig Tijdschrift. 60, 1991: 183-184.

POSPÍSIL, L.-BUČEK, J.-VAŠKU, V.-SKALKA, B.: Isolierung von Dermatophilus congolensis aus einem Unterschenkelgeschwür. Dermatol. Mon. schr., 177, 1991: 525-530.

POSPÍSIL, L.-SKALKA, B.-BUČEK, J.-MOSTER, M.: První izolace Dermatophilus congolensis Van Saceghem 1915 v ČSFR. Čs. epidemiol., 41, 1992: 258-267.

ROBERTS, D. S.: The life-cycle of Dermatophilus dermatonomus, the causal agent of ovine dermatitis. Aust. J. Exp. Biol. Med. Sci., 39, 1961: 463-476. 
ROBERTS, D. S.: The histopathology of epidermal infection with the actinomycete Dermatophilus congolensis. J. Pathol. Bacteriol., 90, 1965: 213-216.

SKALKA, B.-POSPIŚIL, L.: Hemolytic interactions of Dermatophilus congolensis. J. Vet. Med., B 39, 1992: 139-143.

SKALKA, B.-POSPIŚIL, L.: Antigenicity of Dermatophilus congolensis hemolysin. J. Vet. Med., B 40, 1993a: 215-221.

SKALKA, B.-POSPIŚIL, L.: Dermatofilóza - u nás málo známé kožní onemocnění zvírat a lidí. Veterinářství, 43, 1993b: 153-156.

VESTWEBER, J. G.: Difficult dermatologic diagnosis. J. Am. Vet. Med. Ass., 201, 1992: 1695-1696. 